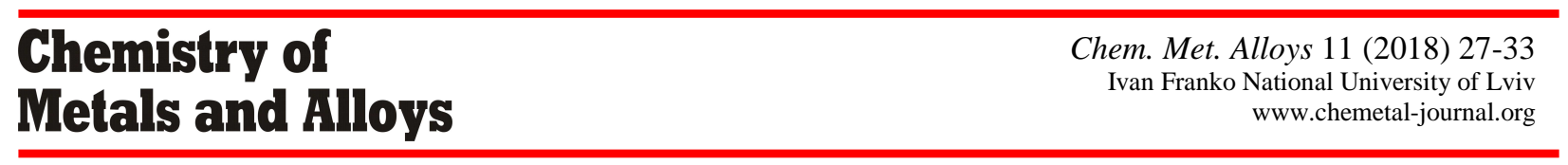

\title{
Phase equilibria in the ternary system Gd-Fe-Zn and electrochemical hydrogenation of the phases
}

\author{
Nataliya CHORNA ${ }^{1}$, Nataliya SAGAN $^{1}$, Oksana ZELINSKA $^{1}$, Vasyl KORDAN ${ }^{1}$, Anatoliy ZELINSKIY ${ }^{1}$, \\ Volodymyr PAVLYUK ${ }^{1}$ \\ ${ }^{1}$ Department of Inorganic Chemistry, Ivan Franko National University of Lviv, \\ Kyryla i Mefodiya St. 6, 79005 Lviv, Ukraine \\ * Corresponding author. E-mail: chorna.nata15@gmail.com
}

Received May 1, 2018; accepted June 27, 2018; available on-line January 1, 2019

\begin{abstract}
The interaction of the components in the ternary system $\mathrm{Gd}-\mathrm{Fe}-\mathrm{Zn}$ was investigated for the first time using $X$-ray powder diffraction and energy-dispersive $X$-ray analysis. The isothermal section of the phase diagram at $500^{\circ} \mathrm{C}$ was constructed over the whole concentration range. The existence of the ternary compound $\mathrm{Gd}_{2} \mathrm{Fe}_{2} \mathrm{Zn}_{15}\left(\mathrm{Th}_{2} \mathrm{Zn}_{17}\right.$-type, space group $\left.R-3 m, a=0.90025(10) \mathrm{nm}, c=1.3160(3) \mathrm{nm}\right)$ was confirmed at $500^{\circ} \mathrm{C}$ in the $\mathrm{Gd}-\mathrm{Fe}-\mathrm{Zn}$ system. A new ternary compound $\sim \mathrm{Gd}_{13}(\mathrm{Fe}, \mathrm{Zn})_{58}\left(\mathrm{Gd}_{13} \mathrm{Zn}_{58}\right.$-type, space group $P 6_{3} / \mathrm{mmc}$, $a=1.4306(5) \mathrm{nm}, c=1.4000(2) \mathrm{nm})$ was obtained. The efficiency of electrochemical hydrogenation of the binary phases $\mathrm{GdZn}_{1} \mathrm{GdZn}_{2}, \mathrm{GdFe}_{2}$ and the solid solutions on their basis was studied in Ni-MH battery prototypes. $\mathrm{GdZn}_{1-x} \mathrm{Fe}_{x}$ with cubic CsCl-type structure reversibly absorbs $0.006 \mathrm{H} / \mathrm{f}$.u. when $x=0$, and $0.009 \mathrm{H} /$ f.u. when $x=0.04$. $\mathrm{GdZn}_{2-x} \mathrm{Fe}_{x}$ with orthorhombic $\mathrm{KHg}_{2}$-type structure absorbs $0.012 \mathrm{H} / \mathrm{f}$.u. when $x=0$, and $0.016 \mathrm{H} / \mathrm{f}$.u. when $x=0.06$. $\mathrm{GdFe}_{2-x} \mathrm{Zn}_{x}$ with cubic $\mathrm{MgCu}_{2}$-type structure absorbs the largest amount of hydrogen, that is $0.023 \mathrm{H} / \mathrm{f}$.u. when $x=0$, and $0.027 \mathrm{H} / \mathrm{f}$.u. when $x=0.06$. The influence of composition, crystal structure and chemical activity of the studied electrode materials in alkaline media on their hydrogen capacity and electrochemical characteristics is discussed.
\end{abstract}

Phase equilibria / Intermetallic compound / Solid solution / Electrochemical hydrogenation / Ni-MH battery

\section{Introduction}

With the development of materials science numerous studies are carried out on multicomponent metallic systems as a source for new perspective materials. Accumulation of experimental data on the phase diagrams of the systems, and on the stability ranges, crystal structures, physical and chemical properties of new intermetallic compounds, helps establishing a connection between the composition, structure and properties of substances and makes the process of creation of new materials more purposeful. Systems on the basis of rare-earth and $3 d$-transition metals are among those that attract the attention of scientists because of a variety of interesting and prospective properties of their alloys. Among these is their ability to reversibly absorb/desorb hydrogen, which makes it possible to use the alloys for hydrogen storage and as electrode materials in nickel metal-hydride batteries [1-4]. Hydrogen atoms in the structures of intermetallic compounds usually occupy octahedral and tetrahedral voids. Preferably filled are the voids formed by atoms with chemical affinity for hydrogen, a radius of at least $0.04 \mathrm{~nm}$, and a minimum $\mathrm{H}-\mathrm{H}$ distance of about $0.2 \mathrm{~nm}$ [5].
Despite the great interest in these systems, the interaction of the components in many of them remains poorly understood and the phase diagrams undetermined. This work continues a systematic study of such systems and is devoted to the investigation of the phase equilibria in the ternary system $\mathrm{Gd}-\mathrm{Fe}-\mathrm{Zn}$, the crystal structures and homogeneity ranges of the identified phases and electrochemical hydrogenation. The study of other $R-\mathrm{Fe}-\mathrm{Zn}$ systems remains limited to ternary phases with specific compositions and their crystal structures, with the exception of the $\mathrm{La}-\mathrm{Fe}-\mathrm{Zn}, \mathrm{Ce}-\mathrm{Fe}-\mathrm{Zn}$ and $\mathrm{Tb}-\mathrm{Fe}-\mathrm{Zn}$ systems, for which isothermal sections have been constructed. The existence of one ternary compound, referred to as $\mathrm{La}_{2} \mathrm{Fe}_{3} \mathrm{Zn}_{14}$ [6], was reported in the $\mathrm{La}-\mathrm{Fe}-\mathrm{Zn}$ system at $400^{\circ} \mathrm{C}$, but an investigation of the crystal structure of this compound led to the composition $\mathrm{La}_{2} \mathrm{Fe}_{2} \mathrm{Zn}_{15}$ [7]. Three compounds were observed in the $\mathrm{Ce}-\mathrm{Fe}-\mathrm{Zn}$ system at $200^{\circ} \mathrm{C}$ [8] and the crystal structures were determined for two of them, $\mathrm{CeFe}_{1.2} \mathrm{Zn}_{1.8}$ and $\mathrm{Ce}_{2} \mathrm{Fe}_{3} \mathrm{Zn}_{14}$ [6]. The crystal structures of two ternary compounds, $\mathrm{TbFe}_{2} \mathrm{Zn}_{20}$ and $\mathrm{Tb}_{2} \mathrm{Fe}_{3} \mathrm{Zn}_{14}$, were reported in the $\mathrm{Tb}-\mathrm{Fe}-\mathrm{Zn}$ system at $400^{\circ} \mathrm{C}$ [9]. A series of isotypical, zinc-rich compounds $R_{2} \mathrm{Fe}_{3} \mathrm{Zn}_{14}$ was observed in the ternary systems of most of the rare- 
earth elements [6]. In the systems with late rare-earth elements ( $\{\mathrm{Gd}, \mathrm{Tb}, \mathrm{Dy}, \mathrm{Ho}, \mathrm{Er}, \mathrm{Tm}, \mathrm{Lu}\}-\mathrm{Fe}-\mathrm{Zn})$ the same group [10] reported another series of isotypical zinc-rich compounds with the composition $R \mathrm{Fe}_{2} \mathrm{Zn}_{20}$. In addition, the existence of $\mathrm{Sm}_{4} \mathrm{Fe}_{5} \mathrm{Zn}_{7}$ [11], $\mathrm{Pr}_{6} \mathrm{Fe}_{13} \mathrm{Zn}$ and $\mathrm{Nd}_{6} \mathrm{Fe}_{13} \mathrm{Zn}$ [12] was observed in the corresponding ternary systems.

\section{Experimental}

The phase equilibria in the ternary system $\mathrm{Gd}-\mathrm{Fe}-\mathrm{Zn}$ were studied through the analysis of 35 binary and ternary alloys. The synthesis of the alloys, each with a total mass of about $1 \mathrm{~g}$, was carried out by arc melting of the elemental components (all with nominal purity $>99.9$ wt. \%) under an argon atmosphere at a pressure of $100 \mathrm{kPa}$. For better homogenization, the alloys were annealed in evacuated silica ampoules at $500^{\circ} \mathrm{C}$ for $1500 \mathrm{~h}$ and quenched in cold water. The compositions of the samples were controlled by comparison of each alloy with the mass of the initial batch. In the cases where an accurate determination of the composition was deemed necessary an energydispersive X-ray analysis was carried out on REMMA-102-02 and EVO 40XVP electron microscopes.

Powder X-ray diffraction was the main method used for the phase analysis of the alloys. Powder patterns of the samples were obtained at room temperature from well-ground samples using a powder diffractometer DRON-2.0M $\left(\mathrm{Fe} K_{\alpha}\right.$-radiation, $20^{\circ} \leq 2 \theta \leq 100^{\circ}, 1 \% \mathrm{~min}$ scan speed). For phase identification, the experimental powder patterns were compared with those calculated by the program PowderCell [13], and the lattice parameters of the observed phases were refined by the leastsquares method using Latcon [14] and FullProf programs [15].

Electrochemical hydrogenation of the binary phases $\mathrm{GdZn}, \mathrm{GdZn}_{2}$ and $\mathrm{GdFe}_{2}$, and their ternary derivatives $\mathrm{GdZn}_{1-x} \mathrm{Fe}_{x}, x=0.04, \mathrm{GdZn}_{2-x} \mathrm{Fe}_{x}, x=0.06$, and $\mathrm{GdFe}_{2-x} \mathrm{Zn}_{x}, x=0.06$, was carried out in a twoelectrode Swagelok-type cell. Alloys with a mass of $0.3 \mathrm{~g}$, in the form of powder and mixed with the electrolyte $(6 \mathrm{M} \mathrm{KOH})$ to a homogeneous mass, filled the space of the anode area of the battery. An electrolyte-wetted mixture of fresh nickel(II) hydroxide and graphite (90 and $10 \mathrm{wt} \%$, respectively), added to improve the electric conductivity and reduce the formation of dendrites, filled the space of the cathode area of the battery. A separator made from pressed cellulose and soaked in electrolyte was placed between the electrodes to avoid direct contact. Testing of the batteries was carried out in the galvanostatic regime $(0.5$ or $0.6 \mathrm{~mA})$ over 50 cycles, using a galvanostat MTech G410-2 [16]. Charging of the prototype was carried out at $0.6 \mathrm{~mA}$ (discharging at $0.2 \mathrm{~mA}$ ) to the maximum possible saturation of the anode material by hydrogen at the conditions of the experiment (horizontal plateau on the charge curve). The amount of hydrogen deintercalated from the sample was calculated at discharge using Faraday's law.

The morphology of surfaces and compositions of grains were examined by scanning electron microscopy (electron microscope REMMA-102-02).

\section{Results and discussion}

3.1. Phase equilibria in the $G d-F e-Z n$ ternary system The isothermal section of the $\mathrm{Gd}-\mathrm{Fe}-\mathrm{Zn}$ phase diagram at $500^{\circ} \mathrm{C}$ was constructed over the whole concentration range (Fig. 1). It consists of 20 singlephase regions, 39 two-phase regions and 20 threephase regions.

The existence of the binary compounds shown in Fig. 1 was confirmed under the conditions of the experiment. The compounds GdZn (structure type $\mathrm{CsCl}$, space group $\mathrm{Pm}-3 m$ ), $\mathrm{GdZn}_{2}$ (structure type $\mathrm{KHg}_{2}$, space group Imma) and $\mathrm{GdFe}_{2}$ (structure type $\mathrm{MgCu}_{2}$, space group $F d-3 m$ ) dissolve about 2 at. $\% \mathrm{Fe}$ or $\mathrm{Zn}$, forming limited solid solutions along the corresponding isoconcentrates of gadolinium. The cell volumes of $\mathrm{GdZn}_{1-x} \mathrm{Fe}_{x}$ and $\mathrm{GdZn}_{2-x} \mathrm{Fe}_{x}$ slightly decrease with increasing iron content, and the cell volume of $\mathrm{GdFe}_{2-x} \mathrm{Zn}_{x}$ slightly increases with increasing zinc content, which agrees with the sizes of the atoms $\left(r_{\mathrm{Fe}}=0.126 \mathrm{~nm}, r_{\mathrm{Zn}}=0.133 \mathrm{~nm}\right)$ (Table 1). The variation of the lattice parameters with increasing content of the third component, as well as the results of the EDX-analysis (Fig. 2), proved the existence of homogeneity ranges. Visible homogeneity ranges on the basis of the other binary compounds were not detected at the annealing temperature.

The existence of the ternary compound $\mathrm{Gd}_{2} \mathrm{Fe}_{3} \mathrm{Zn}_{14}$ (structure type $\mathrm{Th}_{2} \mathrm{Zn}_{17}$, space group $R-3 m$, $a=0.8965(2) \mathrm{nm}, \quad c=1.3150(3) \mathrm{nm}) \quad$ [6] was confirmed in the zinc-rich region of the $\mathrm{Gd}-\mathrm{Fe}-\mathrm{Zn}$ system. However, the results of the EDX-analysis for the samples $\mathrm{Gd}_{7.5} \mathrm{Fe}_{10} \mathrm{Zn}_{82.5}$ and $\mathrm{Gd}_{10} \mathrm{Fe}_{15} \mathrm{Zn}_{75}$ (see Fig. 2), showing equal contents of $\mathrm{Gd}$ and $\mathrm{Fe}$ in the ternary phase $\left(\mathrm{Gd}_{10.85} \mathrm{Fe}_{10.97} \mathrm{Zn}_{78.18}\right.$ and $\mathrm{Gd}_{10.58} \mathrm{Fe}_{10.70} \mathrm{Zn}_{78.72}$ ), and the larger values of the lattice parameters $(a=0.90025(10) \mathrm{nm}$, $c=1.3160(3) \mathrm{nm})$, made us doubt the correctness of the composition reported in the literature. A precise investigation of the crystal structure of the compound confirmed our doubts and led to the composition $\mathrm{Gd}_{2} \mathrm{Fe}_{2} \mathrm{Zn}_{15}$, as in similar systems [7,17,18]. A new ternary compound with the composition $\mathrm{Gd}_{18.38} \mathrm{Fe}_{66.73} \mathrm{Zn}_{14.89}$ obtained from the EDX-analysis of the sample $\mathrm{Gd}_{16.5} \mathrm{Fe}_{63.5} \mathrm{Zn}_{20}$ (see Fig. 2) was observed. The crystal structure of this compound is related to the $\mathrm{Gd}_{13} \mathrm{Zn}_{58}$-type (space group $P 6_{3} / m m c$, $a=1.4306(5) \mathrm{nm}, c=1.4000(2) \mathrm{nm})$. Details of the refinements of the crystal structures of the new compounds will be described in a separate publication. 
N. Chorna et al., Phase equilibria in the ternary system Gd-Fe-Zn and electrochemical hydrogenation of ...

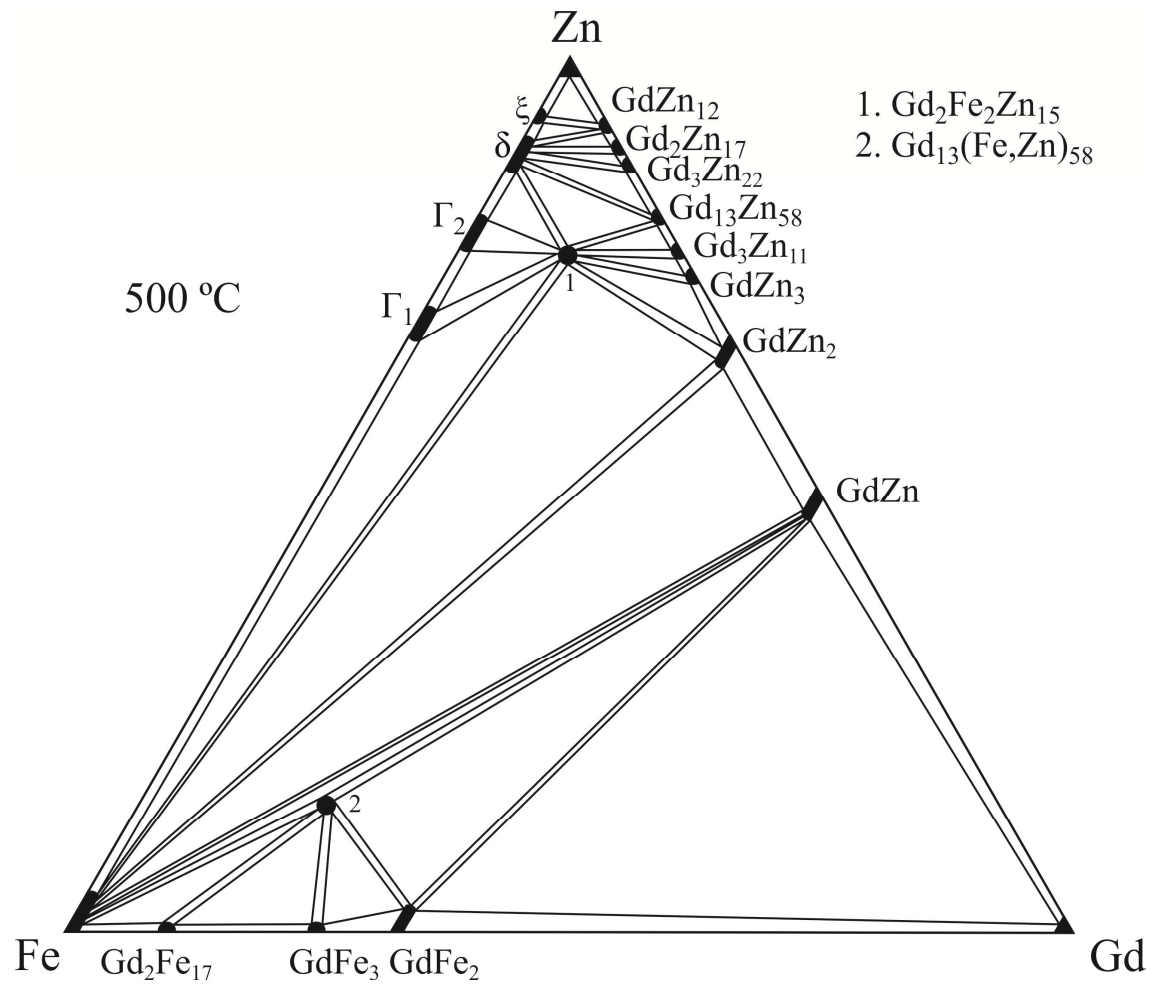

Fig. 1 Isothermal section of the $\mathrm{Gd}-\mathrm{Fe}-\mathrm{Zn}$ phase diagram at $500^{\circ} \mathrm{C}$.

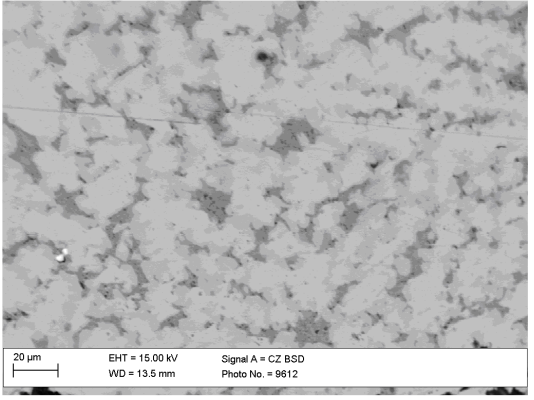

$\mathrm{Gd}_{7.5} \mathrm{Fe}_{10} \mathrm{Zn}_{\mathbf{8 2 . 5}}$ :

dark gray phase $-\mathrm{Gd}_{1.31} \mathrm{Zn}_{98.69}$ gray phase $-\mathrm{Gd}_{10.85} \mathrm{Fe}_{10.97} \mathrm{Zn}_{78.18}$ light gray phase $-\mathrm{Gd}_{16.48} \mathrm{Zn}_{83.52}$

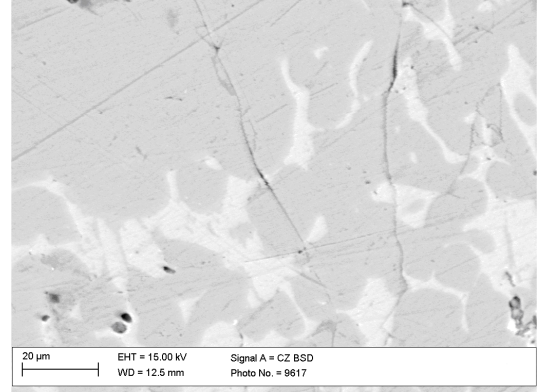

$\mathbf{G d}_{10} \mathrm{Fe}_{15} \mathbf{Z n}_{75}$ :

gray phase $-\mathrm{Gd}_{10.58} \mathrm{Fe}_{10.7} \mathrm{Zn}_{78.72}$ light gray phase $-\mathrm{Gd}_{17.04} \mathrm{Zn}_{82.96}$

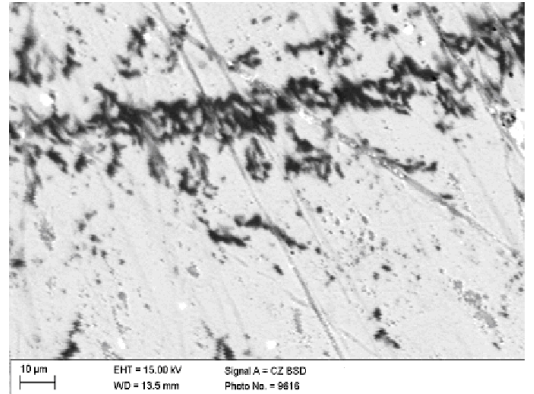

$\operatorname{Gd}_{16.5} \mathrm{Fe}_{63.5} \mathrm{Zn}_{20}$ :

dark gray phase $-\mathrm{Fe}_{93.71} \mathrm{Zn}_{6.29}$ light gray phase $-\mathrm{Gd}_{18.38} \mathrm{Fe}_{66.73} \mathrm{Zn}_{14.89}$

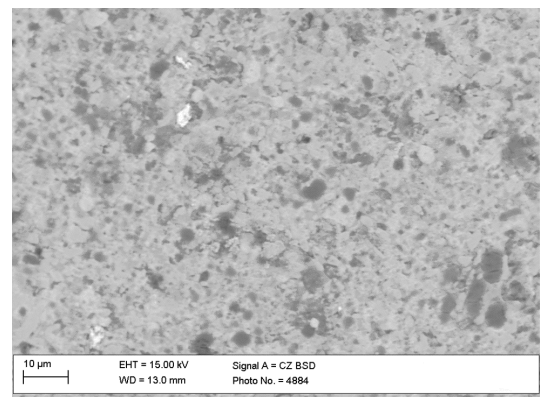

$\mathrm{Gd}_{33.33} \mathrm{Fe}_{33} \mathrm{Zn}_{33.67}$ :

dark gray phase $-\mathrm{Gd}_{35.25} \mathrm{Fe}_{62.72} \mathrm{Zn}_{2.03}$ light gray phase $-\mathrm{Gd}_{35,88} \mathrm{Fe}_{61,79} \mathrm{Zn}_{2,33}$

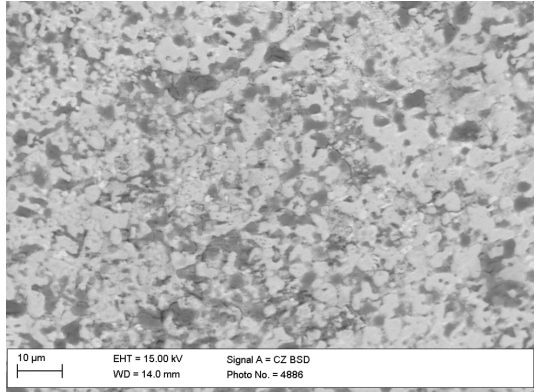

$\mathrm{Gd}_{50} \mathrm{Fe}_{10} \mathrm{Zn}_{40}$ :

dark gray phase $-\mathrm{Gd}_{47.52} \mathrm{Zn}_{52.48}$ light gray phase $-\mathrm{Gd}_{50.27} \mathrm{Fe}_{2.40} \mathrm{Zn}_{47.33}$

Fig. 2 SEM-images of the Gd-Fe-Zn alloys and compositions of the phases obtained by EDX. 
Table 1 Lattice parameters of solid solutions in the Gd-Fe-Zn ternary system and their hydrides.

\begin{tabular}{|c|c|c|c|c|c|}
\hline Composition & $a, \mathrm{~nm}$ & $b, \mathrm{~nm}$ & $c, \mathrm{~nm}$ & $V, \mathrm{~nm}^{3}$ & $\Delta V / V, \%$ \\
\hline \multicolumn{6}{|c|}{$\mathrm{GdZn}_{1-x} \mathrm{Fe}_{x}, x=0-0.04$} \\
\hline $\mathrm{GdZn}$ & $0.3592(7)$ & - & - & $0.0463(3)$ & \multirow{2}{*}{0.432} \\
\hline $\mathrm{GdZnH}_{0.006}$ & $0.3595(2)$ & - & - & $0.0465(1)$ & \\
\hline $\mathrm{GdZn}_{0.96} \mathrm{Fe}_{0.04}$ & $0.3589(1)$ & - & - & $0.0462(1)$ & \multirow{2}{*}{0.216} \\
\hline $\mathrm{GdZn}_{0.96} \mathrm{Fe}_{0.04} \mathrm{H}_{0.009}$ & $0.3592(1)$ & - & - & $0.0463(3)$ & \\
\hline \multicolumn{6}{|c|}{$\mathrm{GdZn}_{2-x} \mathrm{Fe}_{x}, x=0-0.06$} \\
\hline $\mathrm{GdZn}_{2}$ & $0.4503(2)$ & $0.7206(3)$ & $0.7560(5)$ & $0.2453(2)$ & \multirow{2}{*}{0.285} \\
\hline $\mathrm{GdZn}_{2} \mathrm{H}_{0.012}$ & $0.4507(7)$ & $0.7210(6)$ & $0.7571(5)$ & $0.2460(4)$ & \\
\hline $\mathrm{GdZn}_{1.94} \mathrm{Fe}_{0.06}$ & $0.4500(3)$ & $0.7204(5)$ & $0.7556(7)$ & $0.2450(2)$ & \multirow{2}{*}{0.204} \\
\hline $\mathrm{GdZn}_{1.94} \mathrm{Fe}_{0.06} \mathrm{H}_{0.016}$ & $0.4501(2)$ & $0.7209(3)$ & $0.7566(5)$ & $0.2455(2)$ & \\
\hline \multicolumn{6}{|c|}{$\mathrm{GdFe}_{2-x} \mathrm{Zn}_{x}, x=0-0.06$} \\
\hline $\mathrm{GdFe}_{2}$ & $0.7376(2)$ & - & - & $0.4014(3)$ & \multirow{2}{*}{0.897} \\
\hline $\mathrm{GdFe}_{2} \mathrm{H}_{0.023}$ & $0.7399(1)$ & - & - & $0.4050(1)$ & \\
\hline $\mathrm{GdFe}_{1.94} \mathrm{Zn}_{0.06}$ & $0.7380(2)$ & - & - & $0.4019(4)$ & \multirow{2}{*}{1.219} \\
\hline $\mathrm{GdFe}_{1.94} \mathrm{Zn}_{0.06} \mathrm{H}_{0.027}$ & $0.7409(1)$ & - & - & $0.4068(2)$ & \\
\hline
\end{tabular}

\subsection{Electrochemical hydrogenation of the phases}

Three solid solutions on the basis of binary phases, namely $\quad \mathrm{GdZn}_{1-x} \mathrm{Fe}_{x}, \quad x=0-0.04, \quad \mathrm{GdZn}_{2-x} \mathrm{Fe}_{x}$, $x=0-0.06$, and $\mathrm{GdFe}_{2-x} \mathrm{Zn}_{x}, x=0-0.06$, were selected for electrochemical hydrogenation and served as negative electrodes in nickel metal-hydride battery prototypes. The electrochemical reactions that take place on the electrodes can be represented by the following scheme:

$$
\begin{gathered}
\mathrm{Gd}_{a} \mathrm{Fe}_{b} \mathrm{Zn}_{c}+z \mathrm{H}_{2} \mathrm{O}+\underset{z \overline{\mathrm{e}} \underset{\text { discharge }}{\stackrel{\text { charge }}{\rightleftarrows}}}{ } \mathrm{Gd}_{a} \mathrm{Fe}_{b} \mathrm{Zn}_{c} \mathrm{H}_{z}+ \\
\mathrm{Ni}(\mathrm{OH})_{2}+z \mathrm{OH}^{-} \underset{\text { discharge }}{\stackrel{\text { charge }}{\longleftarrow}} \mathrm{NiOOH}+z \mathrm{H}_{2} \mathrm{O}+z \overline{\mathrm{e}} .
\end{gathered}
$$

From the charge curves of the samples (Figs. $3 a, c, e, g, i, k$ ) we can see that the anode materials made from these alloys required significant activation of their surfaces, which lasted almost to the $10^{\text {th }}$ cycle and involved the destruction of the oxide film and the opening of pores for activation of the bulk. The charging potential of the battery prototypes gradually increased from the $10^{\text {th }}$ to the $50^{\text {th }}$ cycle with increasing content of absorbed hydrogen. The character of the discharge curves (Figs. $3 b, d_{2}, h, j, l$ ) confirmed that only after activation the battery prototypes began to work in optimal mode. The nominal voltage of the battery prototypes during discharging was in the range 1.1-1.3 V, typical for $\mathrm{Ni}-\mathrm{MH}$ batteries.

The efficiency of the electrochemical hydrogenation of $\mathrm{GdZn}_{1-x} \mathrm{Fe}_{x}, x=0-0.04$, was studied on the samples $\mathrm{Gd}_{50} \mathrm{Zn}_{50}$ and $\mathrm{Gd}_{50} \mathrm{Zn}_{45} \mathrm{Fe}_{5}$. X-ray powder diffraction of the electrode materials before hydrogenation confirmed the formation of the expected phases $\mathrm{GdZn}$ and $\mathrm{GdZn}_{1-x} \mathrm{Fe}_{x}, \quad x=0.04$, respectively. After the electrochemical hydrogenation, the samples did not undergo significant changes: the powder patterns contained reflections of the expected phase $\mathrm{GdZn}_{1-x} \mathrm{Fe}_{x}$, $x=0-0.04$, but less intensive and broader. The lattice parameters of the corresponding hydrides had increased (see Table 1). In the case of the iron-doped sample we also observed reflections from $\mathrm{Gd}_{2} \mathrm{O}_{3}$ as a by-product of the reaction between the alloy and the electrolyte. The maximum amount of hydrogen deintercalated during the discharging process was $0.006 \mathrm{H} /$ f.u. for $\mathrm{GdZn}$ and $0.009 \mathrm{H} /$ f.u. for $\mathrm{GdZn}_{1-x} \mathrm{Fe}_{x}$, $x=0.04$, under the experimental conditions. As the number of charge-discharge cycles and the time of immersion in the electrolyte medium increased, the anode materials became partially amorphous, as evidenced by the appearance of a broad maximum on the powder patterns of the samples after hydrogenation. Similar changes were observed for all of the studied electrode materials.

The electrochemical hydrogenation of $\mathrm{GdZn}_{2-x} \mathrm{Fe}_{x}$, $x=0-0.06$, was carried out on samples with the compositions $\mathrm{Gd}_{33.3} \mathrm{Fe}_{66.7}$ and $\mathrm{Gd}_{33.3} \mathrm{Zn}_{64.72} \mathrm{Fe}_{2}$. The phase analysis of the electrode materials, based on the results of X-ray powder diffraction, showed that they contained the expected phases $\mathrm{GdZn}_{2}$ and $\mathrm{GdZn}_{2-x} \mathrm{Fe}_{x}$, $x=0-0.06$, respectively. After the electrochemical hydrogenation the powder patterns of the samples contained the patterns of the initial phases, but with less intensive and broader reflections. The lattice parameters of the hydrides had increased (see Table 1). Under the experimental conditions, the maximum amount of hydrogen deintercalated during the discharging process slightly increased from $0.012 \mathrm{H} /$ f.u. for $\mathrm{GdZn}_{2}$ to $0.016 \mathrm{H} /$ f.u. for $\mathrm{GdZn}_{2-x} \mathrm{Fe}_{x}$, $x=0.06$.

The study of the electrochemical hydrogenation of the solid solution $\mathrm{GdFe}_{2-x} \mathrm{Zn}_{x}, x=0-0.06$, was carried out on the samples $\mathrm{Gd}_{33.3} \mathrm{Fe}_{66.7}$ and $\mathrm{Gd}_{33.3} \mathrm{Fe}_{64.7} \mathrm{Zn}_{2}$. The phase analysis showed that both samples contained the expected phase $\mathrm{GdFe}_{2-x} \mathrm{Zn}_{x}, x=0-0.06$. 
N. Chorna et al., Phase equilibria in the ternary system Gd-Fe-Zn and electrochemical hydrogenation of ...
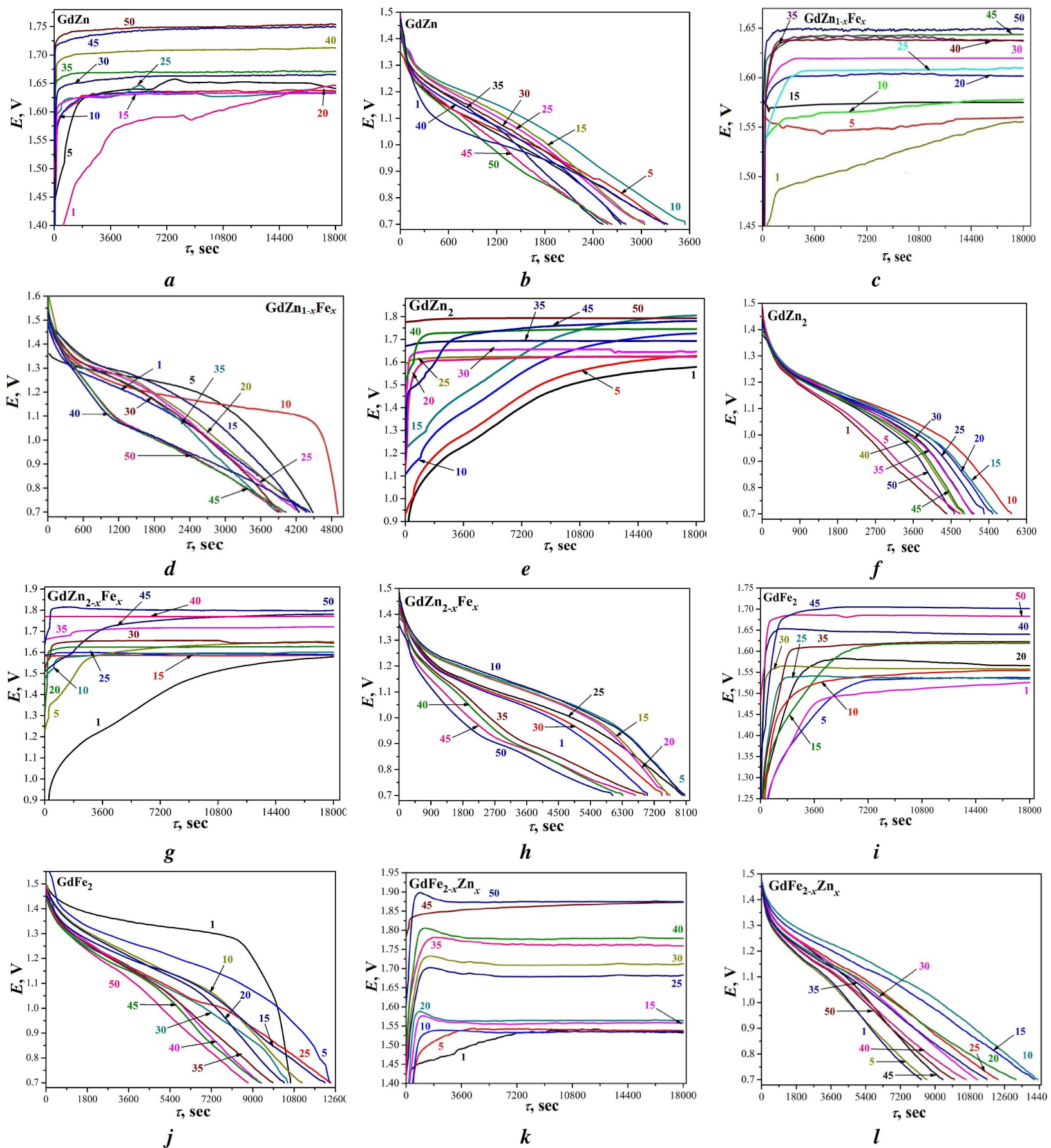

Fig. 3 Selected charge-discharge curves for $\mathrm{GdZn}, \mathrm{GdZn}_{1-x} \mathrm{Fe}_{x}, x=0.04, \mathrm{GdZn}_{2}, \mathrm{GdZn}_{2-x} \mathrm{Fe}_{x}, x=0.06, \mathrm{GdFe}_{2}$ and $\mathrm{GdFe}_{2-x} \mathrm{Zn}_{x}, x=0.06$ (digits indicate the number of charge or discharge cycles).

After the electrochemical hydrogenation, the samples of the electrode materials had not changed significantly, their powder pattern contained all the reflections from the initial phases, but less intensive and broader. The lattice parameters of the hydrides slightly increased (see Table 1). Moreover, reflections from the by-product of the interaction between the alloy and electrolyte, namely $\mathrm{Gd}_{2} \mathrm{O}_{3}$, had also appeared on the powder patterns after the electrochemical process. Under the experimental conditions, the maximum amount of hydrogen deintercalated after the discharging process was the largest among all the phases: $\sim 0.023 \mathrm{H} / \mathrm{f}$.u. for $\mathrm{GdFe}_{2}$ and $\sim 0.027 \mathrm{H} /$ f.u. for $\mathrm{GdFe}_{2-x} \mathrm{Zn}_{x}, x=0.06$. The EDX analysis of samples of the electrodes after the electrochemical process showed almost the same quantitative $\mathrm{Gd} / \mathrm{Fe}$ and $\mathrm{Gd} / \mathrm{Fe} / \mathrm{Zn}$ ratios as in the initial samples. Scanning electron microscopy and 
EDX-analysis (Fig. 4) revealed considerable changes of the surface morphology and grain size of the materials before and after electrochemical hydrogenation because of partial amorphization of the materials.

On analyzing the hydrogen sorption properties and the ability to undergo reversible electrochemical hydrogenation of the investigated phases, we noticed a relation between the structure type and the composition of the phase and the amount of hydrogen that the phase can absorb reversibly. The longest time of discharge had the battery prototype with an anode material based on the Laves phase $\mathrm{GdFe}_{2-x} \mathrm{Zn}_{x}$ (structure type $\mathrm{MgCu}_{2}$ ). Shorter time of discharge had the battery prototype on the basis of $\mathrm{GdZn}_{2-x} \mathrm{Fe}_{x}$ (structure type $\mathrm{KHg}_{2}$ ), and the shortest time of discharge had the battery prototype on the basis of $\mathrm{GdZn}_{1-x} \mathrm{Fe}_{x}$ (structure type $\mathrm{CsCl}$ ). This can be related with the reduction of their chemical activity in the medium of the electrolyte $(6 \mathrm{M} \mathrm{KOH})$ and the ability for reversible intercalation of hydrogen into their structures. It is obvious that phases with voids more suitable for the inclusion of hydrogen show a better turnover; equally important is the coordination environment of the $\mathrm{H}$-atoms. Preferred sites are usually octahedral voids formed by transition metal and rare-earth atoms, and tetrahedral voids formed by transition metal atoms. In our case (Fig. 5) the most suitable sites are the tetrahedral voids in $8 a(000)$ of space group $F d-3 m$ (origin choice 1), that are present in the structure of the Laves phase $\mathrm{GdFe}_{2-x} \mathrm{Zn}_{x}$, $x=0.06 \quad\left(d_{M-\mathrm{H}}=0.1604 \mathrm{~nm}\right)$. In the structure of
$\mathrm{GdZn}_{1-x} \mathrm{Fe}_{x}, x=0.04$ (assuming $\mathrm{Gd}$ in $1 a$ and $\mathrm{Zn} / \mathrm{Fe}$ in $1 b$ of space group $P m-3 m$ ), the H-atoms can occupy the octahedral voids in $3 c\left(0 \frac{1}{2} 1 / 2\right)\left(d_{\mathrm{Gd}-\mathrm{H}}=0.2539 \mathrm{~nm}\right.$, $\left.d_{M-\mathrm{H}}=0.1796 \mathrm{~nm}\right)$ or the tetrahedral voids in $12 \mathrm{~h}$ $\left(\begin{array}{lll}0 & 0 & 1 / 2\end{array}\right)\left(d_{\mathrm{Gd}-\mathrm{H}}=d_{M-\mathrm{H}}=0.2008 \mathrm{~nm}\right)$, formed by rareearth and transition metal atoms. The octahedral voids in $3 d(1 / 200)$ are too small to contain hydrogen atoms $\left(d_{\mathrm{Gd}-\mathrm{H}}=0.1796 \mathrm{~nm}\right)$. In the structure of $\mathrm{GdZn}_{2-x} \mathrm{Fe}_{x}$, $x=0.06$, the H-atoms can occupy the space between the layers formed by rare-earth and transition metals in $x z$ planes (setting Imma) and have coordination polyhedra in the form of distorted trigonal (shortest distances $d_{\mathrm{Gd}-\mathrm{H}}=0.2349 \mathrm{~nm}, d_{M-\mathrm{H}}=0.1893 \mathrm{~nm}$ ) or tetragonal prisms (shortest distances $d_{\mathrm{Gd}-}$ $\left.\mathrm{H}=0.2883 \mathrm{~nm}, d_{M-\mathrm{H}}=0.1843 \mathrm{~nm}\right)$.

\section{Conclusions}

In the investigated $\mathrm{Gd}-\mathrm{Fe}-\mathrm{Zn}$ system, we confirmed the existence of the ternary compound $\mathrm{Gd}_{2} \mathrm{Fe}_{2} \mathrm{Zn}_{15}$ and discovered the existence of a new ternary compound $\sim \mathrm{Gd}_{13}(\mathrm{Fe}, \mathrm{Zn})_{58}$. The compounds crystallize in the same structure types as the binary compounds $\operatorname{Gd}_{2} M_{17}$ and $\mathrm{Gd}_{13} \mathrm{Zn}_{58}$, respectively. The ability to stabilize binary structure types with the addition of the third component is due to the similarity of the electron configuration of $\mathrm{Zn}$ and $\mathrm{Fe}$ (both are $3 d$-elements), the comparable size of the $\mathrm{Fe}$ and $\mathrm{Zn}$ atoms and their relatively easy interchange. This similarity also led to the formation of solid solutions of substitution along rare-earth isoconcentrates.

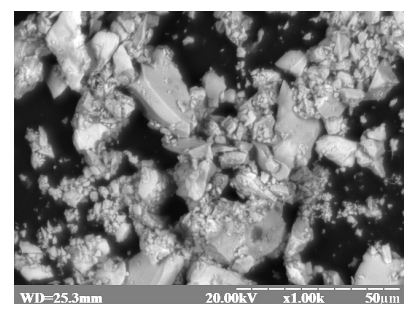

$\mathbf{G d}_{0.93} \mathbf{F e}_{2.07}$

a

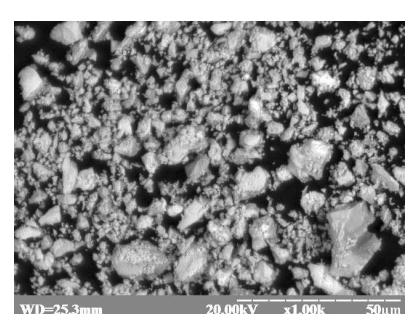

$\mathbf{G d}_{0.99} \mathbf{F e}_{2.01}$

$b$

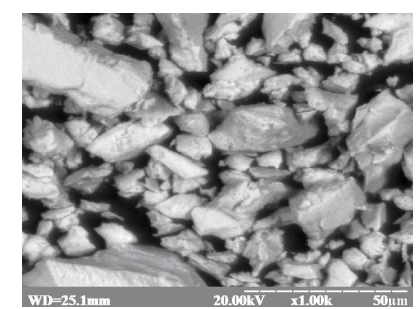

$\mathbf{G d}_{0.97} \mathbf{Z n}_{1.97} \mathrm{Fe}_{0.06}$

c

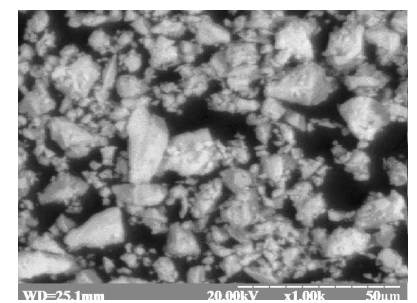

$\mathbf{G d}_{1.13} \mathbf{Z n}_{1.84} \mathrm{Fe}_{0.03}$

d

Fig. 4 SEM-images of $\mathrm{GdFe}_{2}$ and $\mathrm{GdFe}_{2-x} \mathrm{Zn}_{x}$ before $(a, c)$ and after 50 cycles $(b, d)$ of hydrogenation (the average composition of the sample is shown below the picture).
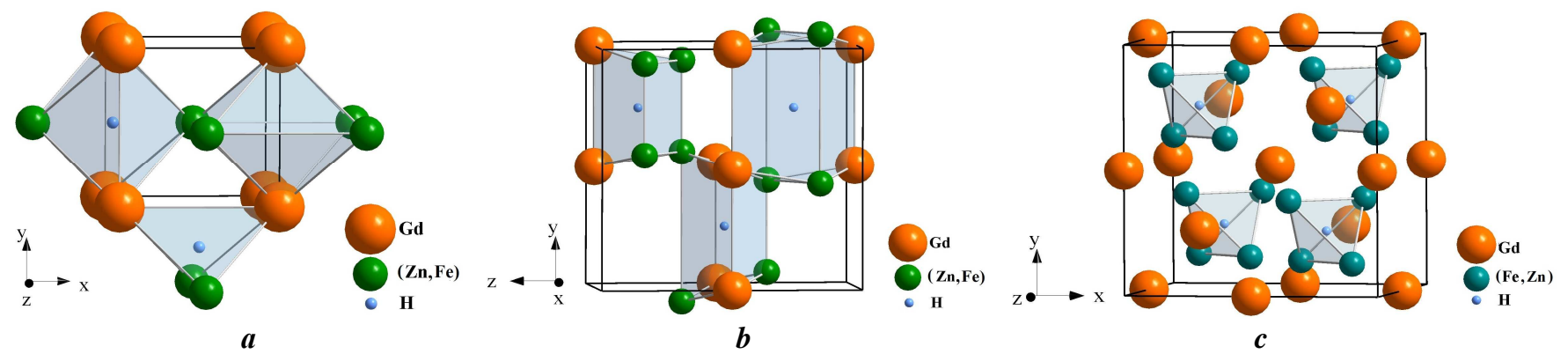

Fig. 5 The crystal structures of $\operatorname{GdZn}_{1-x} \mathrm{Fe}_{x}(a), \mathrm{GdZn}_{2-x} \mathrm{Fe}_{x}(b)$ and $\mathrm{GdFe}_{2-x} \mathrm{Zn}_{x}(c)$ highlighting voids suitable for electrochemical hydrogenation. 
Doping of the binary compounds $\mathrm{GdZn}$ and $\mathrm{GdZn}_{2}$ by iron improved the electrochemical capacity, increased the amount of intercalated hydrogen, thanks to increased corrosion resistance of the doped specimens in alkaline media. Comparing the electrochemical characteristics of the investigated samples of electrode materials, we see that the best results were obtained for $\mathrm{GdFe}_{2-x} \mathrm{Zn}_{x}$, which can be explained by the peculiarities of its crystal structure belonging to the Laves phases, which are well-known as hydrogen storage and electrode materials in nickel metal-hydride batteries. Doping of the binary compound $\mathrm{GdFe}_{2}$ by zinc also improved the electrochemical capacity of the corresponding of the $\mathrm{Ni}-\mathrm{MH}$ battery prototype and increased the amount of intercalated hydrogen. Here the reason is rather related to the larger volume of the voids and coordination environment of the $\mathrm{H}$-atoms. The corrosion resistance of the compound may be further enhanced by doping the alloy by $\mathrm{Co}$ or $\mathrm{Ni}$, which will be the topic of further studies.

\section{Acknowledgments}

The authors are thankful to Roman Serkiz (ScientificTechnical and Educational Center for LowTemperature Studies, Ivan Franko National University of Lviv) and Dr. Vitaliy Shtender (Karpenko PhysicoMechanical Institute, National Academy of Science of Ukraine) for scanning electron microscopy and energy-dispersive X-ray analyses.

\section{References}

[1] J.O. Besenhard (Ed.), Handbook of Battery Materials, Wiley-VCH, Weinheim, 1999, 1023 p.

[2] C.A. Vincent, B. Scrosati (Eds.), Modern Batteries: An Introduction to Electrochemical Power Sources, $2^{\text {nd }}$ Ed., Arnold, London, 1997, 351 p.
[3] M.H. Mintz, I. Javob, D. Shaltiel, in: L. Schlapbach (Ed.), Hydrogen in Intermetallic Compounds II, Springer, Berlin, 1992, p. 285.

[4] J.M. Ogden, Int. J. Hydrogen Energy 24(8) (1999) 709-730.

[5] V.A. Yartys, Usp. Khim. 52(4) (1983) 529-562.

[6] N. Gross, G. Block, W. Jeitschko, Chem. Mater. 14 (2002) 2725-2731.

[7] N. Dychko, O. Zelinska, A. Zelinskiy, V. Pavlyuk, Visn. Lviv Univ., Ser. Khim. 56 (2015) 46-52.

[8] I.M. Opainych, V.V. Pavlyuk, O.I. Bodak, P.K. Starodub, Coll. Abstr. $6^{\text {th }}$ Int. Conf. Cryst. Chem. Intermet. Compd., Lviv, Ukraine, 1995, p. 45.

[9] P.G. Solokha, PhD Thesis, Ivan Franko National University of Lviv, 2008, $244 \mathrm{p}$.

[10] T. Nasch, W. Jeitschko, U.C. Rodewald, Z. Naturforsch. B 52 (1997) 1023-1030.

[11] I.M. Opainych, L.V. Kryvulia, Abstr. Sci. Conf. “Lviv Chemical Readings”, Lviv, Ukraine, 1995, p. 98.

[12] F. Weitzer, A. Leithe-Jasper, P. Rogl, K. Hiebl, A. Rainbacher, G. Wiesinger, W. Steiner, J. Friedl, F.E. Wagner, J. Appl. Phys. 75(12) (1994) 7745-7751.

[13] W. Kraus, G. Nolze, Powder Cell for Windows, Berlin, 1999.

[14] G. King, D. Schwarzenbach, Latcon, Xtal3.7 System, Olthof-Hazekamp, University of Western Australia, 2000.

[15] J. Rodriguez-Carvajal, FULLPROF: A Program for Rietveld Refinement and Pattern Matching Analysis, Abstr. Satell. Meet. Powder Diffr., XV Congr. IUCr, Toulouse, France, 1990, p. 127.

[16] http://chem.Inu.edu.ua/mtech/mtech.htm.

[17] I.M. Opainych, V.V. Pavlyuk, O.I. Bodak, R. Cerny, K. Yvon, Crystallogr. Rep. 41(5) (1996) 809-812.

[18] O.Ya. Zelinska, V.V. Pavlyuk, A.V.Zelinskyy, V.M. Davydov, J. Alloys Compd. 343 (2002) $132-134$ 